\title{
Chronic Obstructive Pulmonary Disease in Women: A Biologically Focused Review with a Systematic Search Strategy [Corrigendum]
}

Han MK. Int J Chron Obstruct Pulmon Dis. 2020;15: $711-721$

Page 718, Disclosure section, the disclosure statement was incomplete, the correct statement is "MeiLan $\mathrm{K}$ Han reports consulting fees from Boehringer Ingelheim, GlaxoSmithKline, AstraZeneca, Merck,
Mylan and Novartis. She also reports research support from Novartis and Sunovion. Boehringer Ingelheim also supported conduction of the systematic search. The author reports no other conflicts of interest in this work."

The author apologizes for this error.

\section{Publish your work in this journal}

The International Journal of COPD is an international, peer-reviewed journal of therapeutics and pharmacology focusing on concise rapid reporting of clinical studies and reviews in COPD. Special focus is given to the pathophysiological processes underlying the disease, intervention programs, patient focused education, and self management protocols. This journal is indexed on PubMed Central, MedLine and CAS. The manuscript management system is completely online and includes a very quick and fair peer-review system, which is all easy to use. Visit http://www.dovepress.com/testimonials.php to read real quotes from published authors. 